\title{
Studi Geologi Pariwisata Pada Jejak Arkeologi Objek Wisata Goa Gajah Sebagai Salah Satu Limpasan Erupsi Gunung Batur Purba
}

\author{
I Kadek Adiana Putra ${ }^{*}$, Ni Wayan Eka Wijayanti ${ }^{1}$ \\ 1 Program Studi Teknik Informatika, STMIK STIKOM, Indonesia \\ *e-mail: putraadiana@ymail.com
}

Article history: Received 28 January 2020; Accepted 10 April 2020; Available online 30 April 2020

\begin{abstract}
Abstrak
Tujuan dari penelitian ini adalah mengaplikasikan peran geowisata dalam eksplorasi informasi sehingga wisatan mendapatkan informasi yang menyeluruh tentang objek wisata Goa Gajah. Metode pengolahan data meliputi morfogi yang dianalisis dari data contur hasil pengolahan citra SRTM, jenis batuan, kandungan mineral yang dianalis dengan parameter fisik data ini di elaborasi dengan sumber informasi pariwisata yang sudah ada, sehingga objek wisata goa gajah memiliki informasi yang detail dan konperhensif. Objek wisata Goa Gajah tersusun atas batuan andesit sebagai batuan basal terletak pada bagian atas, lapilli tuff, dan breksi vulkanik dari depan goa sampai dasar Sungai Petanu. Arca-arca atau peninggalan sejarah yang ditemukan pada lembah sungai atau pada penataran sebagai besar terbentuk dari batuan piroklastik khsusnya ignimbrite. Peran geowisata terlihat sangat signifikan dalam mengungkap peran geologi dalam pengembangan pariwisata khususnya pada objek wisata Gowa Gajah. Lokasi ini dijadikan media karena memiliki sedimen yang keras tidak tembus air (porositas rendah) ini mengindikasikan jika dibangun maka bangunan tidak mudah lapuk atau tahan terhadap korosi.
\end{abstract}

\section{Abstract}

Keywords:

The purpose of this study is to apply the role of geo-tourism in the exploration Geological Formation, Geological Tourism, of information so that tourists get comprehensive information about "Goa Tourism Objects of Goa Gajah" attractions. Data processing methods include morphology analyzed Gajah Temple from contour data resulting from SRTM image processing, rock types, and mineral content analyzed with physical parameters. This data can include elaboration with existing tourism information sources so that Gowa Gajah tourism objects have detailed and comprehensive information. "Goa Gajah" attractions are composed of andesite rocks as basalt rocks located at the top, lapilli tuff, and volcanic breccias from the front of the cave to the bottom of the Petanu River. The statues or historical relics found in river valleys or in the upgrading are largely formed from pyroclastic rocks, especially ignimbrite. The role of geo-tourism looks very significant in uncovering the role of geology in the development of tourism, especially in Gowa Gajah attractions. This location is used as a medium because it has hard sediment that is impermeable to water (low porosity). This indicates that if built, the building is not easily weathered or resistant to corrosion.

Copyright (C) Universitas Pendidikan Ganesha. All rights reserved

\section{Pendahuluan}

Bali terkenal sebagai destinasi wisata dunia, karakter pariwisata Bali yang kuat tidak saja dari segi budaya tetapi juga dari segi sejarah dan peninggalan arkeologi Bali yang begitu eksotis dan menarik untuk di kunjungi (Mudana, 2013). Secara umum objek yang memiliki daya tarik 
wisata sejarah atau arkeologi merupukan tempat suci/ pura, salah satu halnya objek wisata Goa Gajah yang terletak di wilayah Desa Bedulu Kecamatan Blahbatuh Gianyar.

Objek wisata Pura Goa Gajah secara umum dibentuk pada dinding batu dengan jejak arkeologi dan geologi dari lanskap gunung batur purba akan tetapi memiliki fungsi dan tujuan masing-masing. Jejak arkeologi Goa Gajah secara hisoris terbentuk bersamaan pada masa kejayaan kerajaan Bedahulu. Dinas Purbakala RI dalam Juniawati (2011) menyatakan, nama "Goa Gajah" berasal dari kata "Lwa Gajah" yang berarti "Air Gajah" disebut dalam kitab Negarakertagama karangan Mpu Prapanca yang berangka tahun 1365 Masehi.

Latief (2014) menyatakan bahwa, peninggalan arkeologi berupa tempat suci di Bali dikelompokan menjadi tiga kelompok besar. Yang pertama candi tebing atau candi pahatan atau candi padas. Candi/relief lainnya dipahat pada tebing batu gamping di tepi sungai atau sawah. Candi objek wisata Pura Goa Gajah termasuk kelompok ini. Sedangkan Sutawidjaya dalam Mahardika (2015) meneliti batuan dan ignimbrit sekitar pura objek wisata Pura Gunung KawiUbud, menyatakan umur batuan tersebut sekitar 20.150 tahun yang lalu, sedangkan di ubud ignimbrit yang ditemukan $25 \mathrm{~km}$ baratdaya Kaldera Batur, berumur sekitar 29.300 tahun yang lalu.

Menurut Purnomo dalam Assidigy (2015) menyatakan kegiatan vulkanis pada jaman kwarter menghasilkan terbentuknya sejumlah kerucut yang umumnya kini telah tidak aktif lagi. Gunungapi tersebut menghasikan batuan endapan lahar Buyan-Beratan dan Batur, Salah satu dari endapan tersebut membentuk lembah-lembah sungai sepertihalnya lembah Tukad Petanu (lokasi objek wisata Goa Gajah) yang saat ini menjadi sumber arkeologi dari sejarah Kerajaan Bali.

Mengingat gowa gajah dan areanya adalah jejak arkeologi yang dipahat pada dinding batu dan tetap bertahan sampai saat ini sangat cocok ditambahakan sebagai objek geowisata bali khsusnya di Kabupaten Gianyar. Poetry dan baharudin dalam Riswanto \& Andriani (2018) menyatakan, geowisata adalah suatu kegiatan wisata alam yang diselenggarakan secara bertanggung jawab terhadap suatu kawasan yang dilindungi dengan memanfaatkan informasi Geologi.

Khan dalam Hermawan \& Ghani (2017) geowisata menjadi salah satu alat paling kuat untuk melindungi lingkungan. Geowisata merupakan alternatif solusi peningkatan atas pariwisata massal atau "lama" yang menyediakan hubungan sektor yang lebih baik, mengurangi kebocoran manfaat dari suatu negara, menciptakan lapangan kerja lokal, dan menumbuhkan pembangunan berkelanjutan.

Prinsip yang harus diperhatikan dalam mengembangkan geowisata diantaranya adalah (Setyawan, 2013). Pertama, geologically based (Berbasis Geologi): objek/tempat/lokasi yang dijadikan sebagai area geowisata merupakan bentukkan hasil proses gelologi. Aspek fisik yang dijadikan daya tarik wisata tersebut dapat berupa kondisi tanah, kandungan mineral, jenis batuan dan lainnya yang masih berhubungan dengan geologi. Kedua, suistanable (Berkelanjutan): pengembangan dan pengelolaan lokasi geowisata haruslah berkelanjutan agar kelestariannya dapat terjaga. Ketiga, geologically informative (Bersifat Informasi Geologi): di lokasi geowisata dilengkapi dengan informasi tentang sejarah terbentuknya bentukkan geologi tersebut, jadi wisatawan paham mengenai proses alam yang terjadi. Dengan adanya informasi tersebut diharapkan masyarakat sadar dan tidak berupaya merusak keindahan lingkungan di sekitar objek geowisata.

Gunung Batur (1717 mdpl) tergolong gunung purba dimana usianya jauh lebih tua dari Gunung Agung (3142 mdpl) yang merupakan gunung tertinggi di Bali. Gunung Agung sering disebut 'anak' Gunung Batur namun dalam sistem kepercayaan masyarakat Bali. Gunung Batur dikategorikan aktif memiliki sebuah kaldera besar (luas) yang merupakan salah satu yang terbesar (terluas) dan paling indah di dunia. Kaldera ini dinyatakan terbentuk setelah dua letusan besar 29.300 dan 20.150 tahun yang lalu (I. G. Mudana, 2018).

Sutawidjaya dalam Mahardika (2015) menyatakan, berbagai produk abu vulkanik dari Bratan dan Batur yang membuat sebagian besar formasi dan jenis batuan di Bali. Batuan 
tersebut sebagian besar terdiri atas deposit ash-flow (Ignimbrit) yang melapisi dan menutupi sedimen dan batuan vulkanik yang lebih tua. Marinelli \& Tazief dalam Mahardika (2015) menduga kalau formasi kaldera terjadi sekitar 22.000 tahun yang lalu yang diikuti oleh ledakan dan kaldera kedua.

Penemuan awal Goa Gajah dimulai dari laporan Hindia Belanda secara resmi oleh L.C. Heyting pada tahun 1923, yang melaporkan penemuan Arca Ganesha, Patung Tri Lingga, juga Patung Hariti kepada pemerintahan Hindia Belanda. Kemudian Dr. W.F. Stutterhiem mulai melakukan penelitian lanjutan pada tahun 1925, dan pada tahun 1950 situs Arkeologi Kantor Indonesia melalui bagian dari bangunan kuno di Bali yang dipimpin oleh J.L. Krijgman melakukan penelitian dan penggalian pada tahun 1954 hingga tahun 1979, dan mereka menemukan sebuah kolam air suci kuno dengan enam (6) patung perempuan dilengkapi dengan pancuran dada (Puja, 2015).

Hasil observasi awal pada jejak geologi, terlihat formasi, stratigrafi, dan jenis batuan yang unik untuk diungkap jika di hubungkan dengan aktivitas vulkanik Gunung Batur Purba dan aktivitas tektonisme yang berlangsung sampai saat ini. Akan tetapi Keunikan formasi geologi ini belum sepenuhnya belum diungkap, wisatawan baru diberikan informasi mengenai sejarah dari objek dan jenis-jenis peninggalan yang ada. Informasi yang terkait dengan geologi khusunya geologi pariwisata dirasa sangat penting disampaikan sehingga wisatawan yang berkunjung mendapatkan informasi detail selain dari sejarah juga unsur geografis seperti gelogi pariwisata yang berupa unsur batuan yang terdapat di dalamnya. Adapun tujuan dari penelitian ini adalah untuk menganalisis jenis batuan penyusun dan stratigrafi batuan objek wisata Goa Gajah berdasarkan dengan parameter fisik dan mengaplikasikan peran geowisata dalam eksplorasi informasi pada objek Goa Gajah.

\section{Metode}

Penelitian ini merupakan penelitian deskriptif eksploratif, yang bertujuan untuk mengungkap jenis batuan induk, stratigrafi batuan pada objek wisata pura Goa Gajah. Parameter dalam penelitian ini adalah jenis batuan, stratigrafi, dan morfologi batuan yang dapat diukur dengan parameter fisik yang anantinya di korelasikan dengan peran geowisata.

Morfologi dalam penelitian ini adalah proses dan bentukan permukaan bumi yang terdapat padala lokasi penelelitian dan jenis Land Form yang termasuk dalam objek tersebut. Stratigrafi dalam penelitian ini adalah menghubungkan antara morfo aransemen dan morfogenesa batuan dengan urutan kejadian geologi pada lokasi penenlitian berdasarkan parameter fisik. Limpasan vulkanik dalam penelitian ini adalah julamh material vulkanik berbentuk padatan yang berlangsung sampai saat ini baik epusi epusif atau pun eksplosif. Parameter fisik dalam penelitian ini ukuran analisis analisis batuan yang meliputi warna, tekstur, struktur, dan tingkat kekerasan atau unsur yang dapat dianalisis menggunakan panca indera. Sedangkan sejajak arkeologi yang dimaksud disini adalah identifikasi ekofak berupa goa batu dan candi pada dinding batu pada lokasi penelitian sebagai salah satu jejak kebudayaan dinasti Udayana. Peran Geowisata dalam penelitian ini adalah kontibusi Geowisata dalam mengekplorasi kenampakan geologis sebagai untuk meingkatkan pemahaman lingkungan pada lokasi penelitian.

Data mengenai mofologi dan stratigrafi wilayah penelitian, diperoleh dari hasil pengolahan citra topografi SRTM (Shuttle Radar Topography Mission) yang dikalibrasi dengan menggunakan GPS Garmin. Data mengenai jenis batuan dan mineral penyusun, diperoleh dari pengujian dengan parameter fisik yaitu tekstur, struktur, variasi mineral, serta $\mathrm{pH}$. Data tersebut selanjutnya di analisis dengan menggunakan metode deskrip eksploratif sehingga dapat dideskripsikan kondisi geologi dan wilayah penelitian. Data kondisi lingkungan fisik berupa geologi dan geografis merupakan data baru tentang kondisi fisik objek wisata Goa Gajah. Data ini di elaborasi dengan sumber informasi pariwisata yang sudah ada, sehingga objek wisata goa gajah memiliki informasi yang detail dan konperhensif. Detail rancangan penelitian seperti terlihat pada Gambar 1 . 


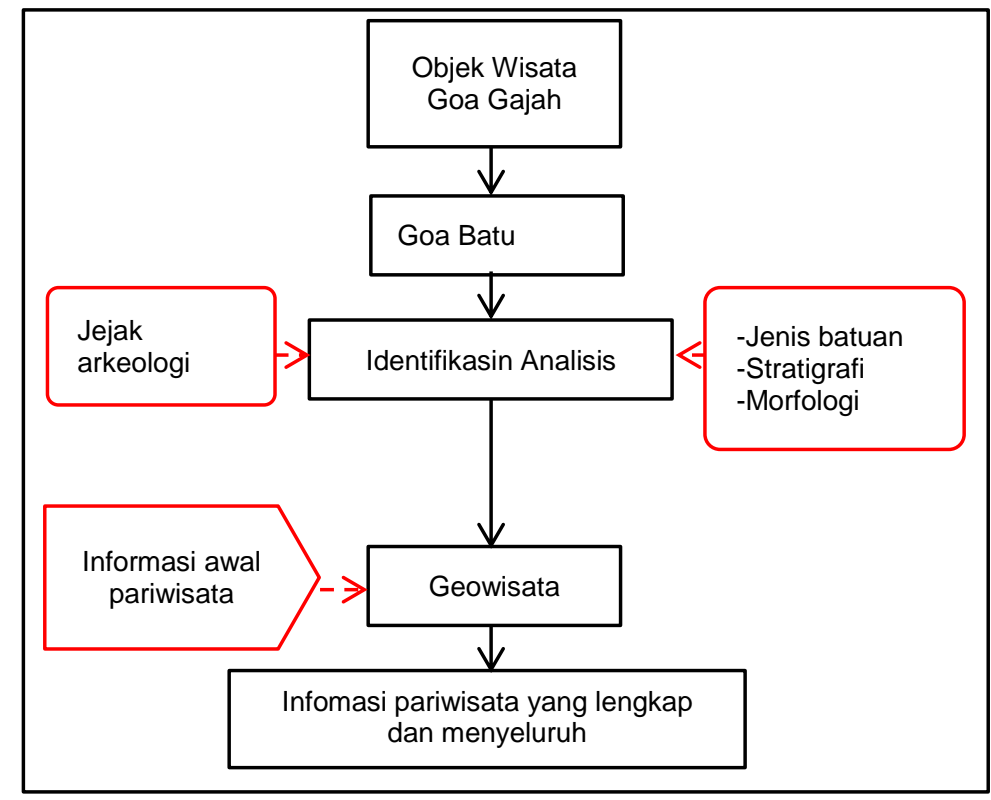

Gambar 1. Rancangan Penelitian

\section{Hasil dan Pembahasan}

Jenis Batuan dan Stratigrafi Batuan Induk Pembentuk Objek Wisata Goa Gajah Berdasarkan Parameter Fisik

1) Jenis, Struktur, dan Tekstur Batuan

Hasil analis struktur dan tekstur, batuan yang menyusun relief luar Goa Gajah diidentifikasi merupakan batuan andesit dan lapili tuff. Batuan Andesit diduga merupakan hasil pengendapan kedua setelah lapilli tuff. Hal ini terlihat dari lapisan relief luar bertekstur halus (afanitik) dengan campuran kristal - kristal berwarna terang gelap sehingga teridentifikasi sebagai andesit. Sedangkan batuan yang terendapkan sebelumnya memiliki tekstur lepas - lepas (Unconsolidated) dimana batuan ini terdiri dari fragmen debu vulkanik (Volcanic Ash) yang dominan $(<2 \mathrm{~mm})$ dan fragmen lapilli $(2-64 \mathrm{~mm})$ sehingga teridentifikasi sebagai lapilli tuff. Untuk lebih jelas mengenai relif batuan bagian depan Goa Gajah dapat dilihat pada Gambar 2.

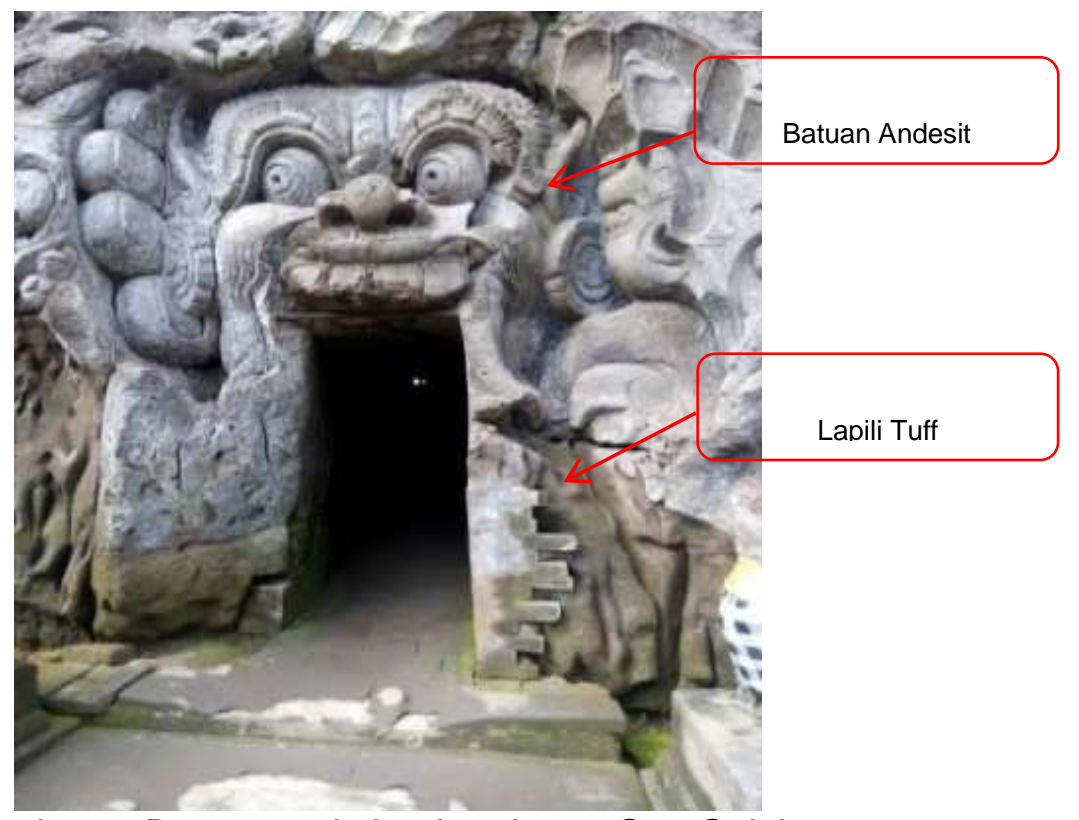

Gambar 2. Batuan pada bagian depan Goa Gajah 
Hasil analisis menggunakan parameter fisik, mulut goa dengan relief sekitarnya terdapat perbedaan meliputi, perbedaan warna dan tekstur. Batuan andesit memiliki tekstur yang lebih kasar dari pada lapilli tuff disekitarnya dan selain itu batuan andesit terlihat kandungan mineral silika berupa plagioklas, kuarsa, piroksen, dan biotit yang saling mengikat (interlocking) saat terbentuk sehingga lebih tahan terhadap pelapukan. Hal ini dapat dibuktikan ketika batuan andesit lebih keras ketika digores dibandingkan dengan lapilli tuff yang mudah rapuh. Untuk lebih jelas perbedaan batuan andesit dan lapilli tuff dapat dilihat pada Gambar 3.

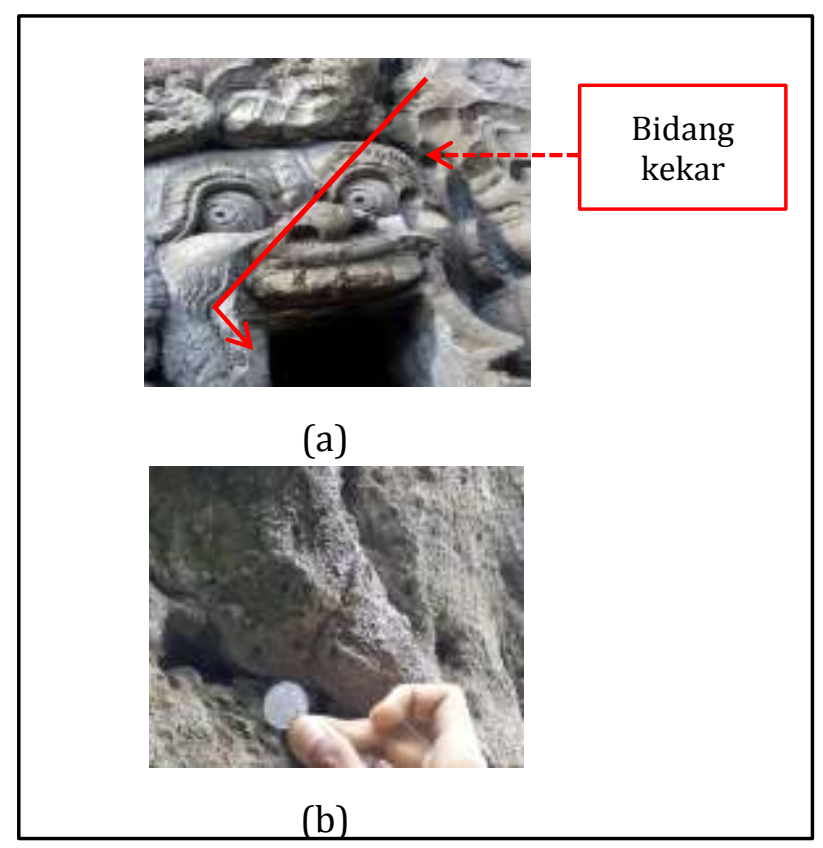

Gambar 3. (a) Batuan Andesit dan (b) Batuan Lapili Tuff

Pada bagian dalam goa, lapilli tuff terjadi proses pemadatan (litifikasi) beberapa kali, hal tersebut diperkuat dengan terdapat layer yang berbeda pada batuan setelah unsur yang unsur homogen kembali terbentuk. Layer tersebut diduga adalah endapan debu vulkanik yang ukurannya $<2 \mathrm{~mm}$ dan telah mengalami oksidasi yang dipengaruhi oleh faktor cuaca kala itu sehingga terlihat seperti serat merah sebagai betuk dari hasil oksidasi besi, yang tampak pada Gambar 4.

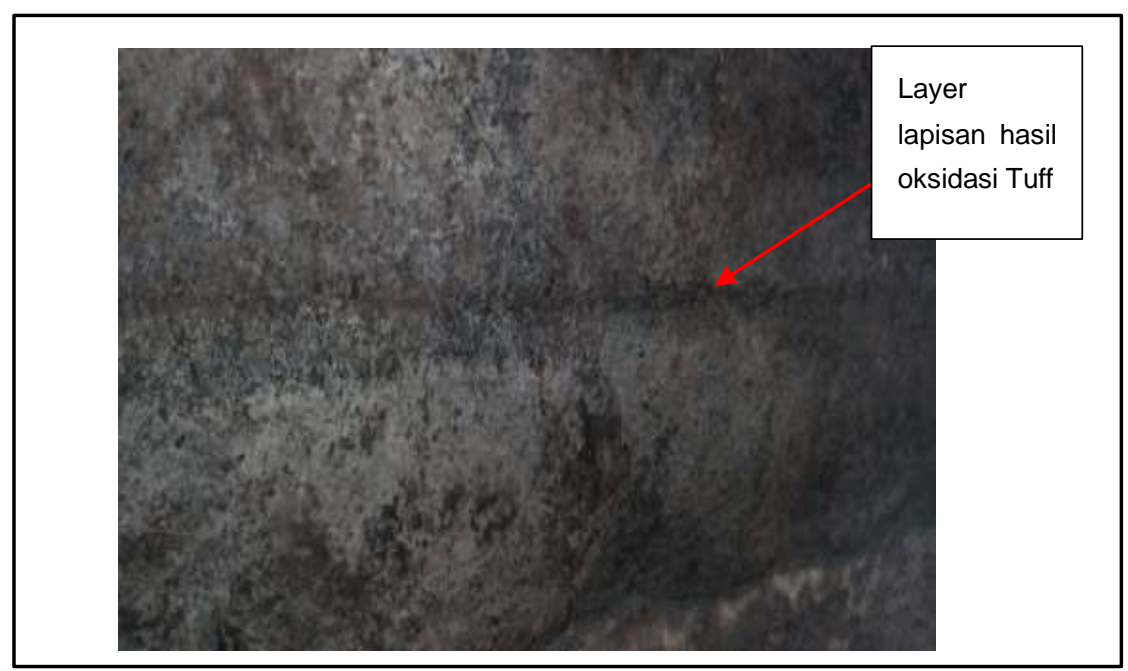

Gambar 4. Layer Batuan Hasil Oksidasi Tuff 
Jejak arkeologi seperti patung ( $A r c a$ ) yang terdapat di depan Goa merupakan pahatan batuan ignimbrite yang memiliki kesamaan dengan batuan yang berada dilembah sungai Petanu. Terdapat inklusi batu apung (pumice) pada batuan yang didominasi oleh fragmen ash tersebut sehingga dapat teridentifikasikan sebagai ignimbrite (welded tuff), seperti pada Gambar 5.

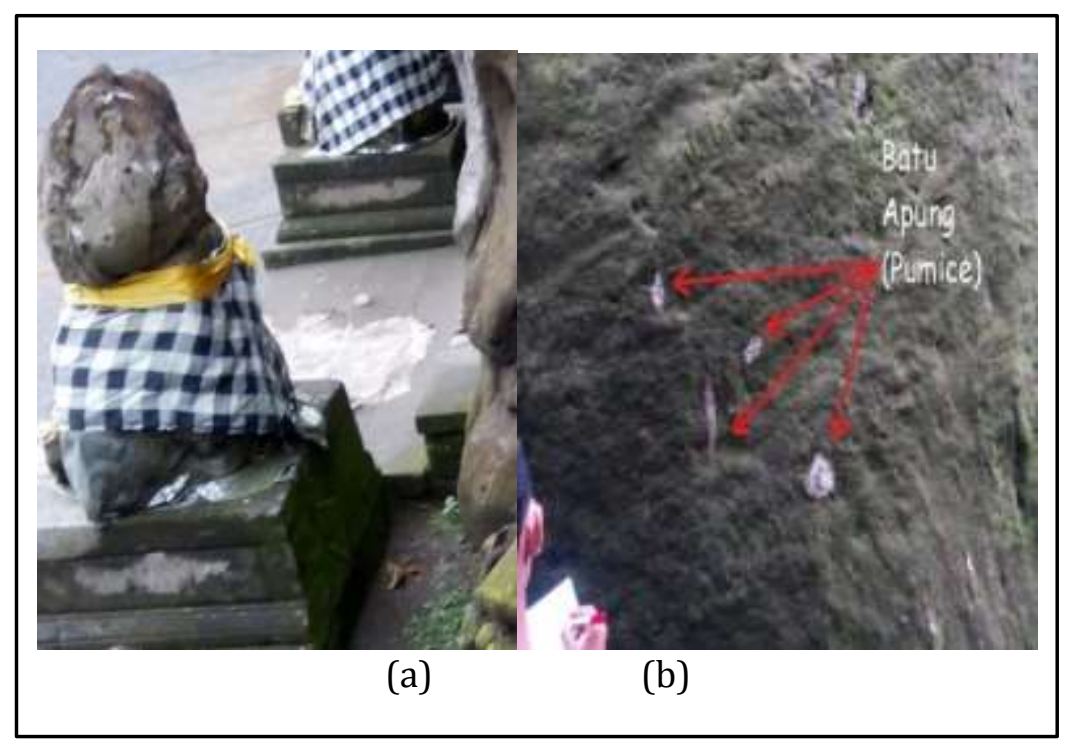

Gambar 5. (a) patung (Arca) dan (b) Jenis batu Ignimbrite

\section{2) Geologi struktur}

Pada batuan pembentuk Goa Gajah terdapat struktur geologi yang mencolok di bagian luar Goa Gajah yaitu dengan tereksposnya kekar lapisan (Bedding Joint) dan kekar diagonal (Diagonal Joint). Kekar tersebut ditemukan pula di dalam goa dengan struktur geologi berupa kekar ekstensi. Kondisi kekar yang terlihat rapuh dan telah mengalami korosi yang mengindikasikan jika kekar tersebut berumur sanghat lama dibandingkan dengan kekar yang bebentuk diagonal yang ditemukan di sekitar goa. Kondisi kekar batuan dapat dilihat pada Gambar 6.



Gambar 6. Kekar Batuan Pada Dinding Goa

Dilihat dari bentuk dan kondisi Bangunan, diduga bahwa terjadi beberapa kali gempa yang sangat dasyat di Bali baik gempa vertikal maupun gempa horisontal jauh setelah Goa Gajah dibuat dan sebelum Goa Gajah ditemukan oleh LC. Heyting pada tahun 1923, Analisa ini 
dibuktikan dengan jurus kekar yang terdapat dalam goa telah mempengaruhi relief ukiran yang terdapat pada bagian luar goa sehingga banyak ukiran pada relif bangunan yang terpotong dan tidak simetris seperti contohnya pada salah satu pintu depan Goa Gajah. Kondisi kekar yang terlihat rapuh dan telah mengalami korosi yang mengindikasikan jika kekar tersebut berumur sanghat lama dibandingkan dengan kekar yang bebentuk diagonal yang ditemukan di sekitar goa.

\section{3) Stratigrafi Batuan}

Proses transportasi dan pengendapan dapat diinterpretasikan dari karakteristik tiaptiap lapisan batuan sedimen, baik dari struktur, ukuran, bentuk, dan distribusi material sedimennya. Kombinasi sedimentology dapat memberikan informasi karakter batuan yang diendapkan. struktur batuan terdapat pelapisan batuan dengan struktur yang beraneka ragam dari atas goa, penataran sampai pada lembah sungai Petanu yang terdapat pada area objek Wisata Goa Gajah.

Lembah sungai transportasikan material hasil litifikasi batuan secara berlahan dan membentuk huruf V sehingga stratigrafi batuan induk dapat diamati lebih jelas. Material Erupsi gunungapi membentuk batuan sediemen dengan pelapisan yang berbeda, pada bagaian bagian bawah terlihat formasi batuan ignimbrite yang tersebar sepanjang dasar sungai dan sekitarnya dengan posisi daerah paling bawah, pada bagian atas ditemukan jenis batuan lapilli tuff dari penataran pura sampai setengah dari dinding goa, diatasnya merupakan batuan basal (andesit) pada muka goa sampai pada tebing. Stratigrafi batuan penyusun objek wisata Goa Gajah dimualai dari batuan berjenis basal sampai ignimbrite yang dapat dilihat pada Gambar 7 dan Gambar 8.

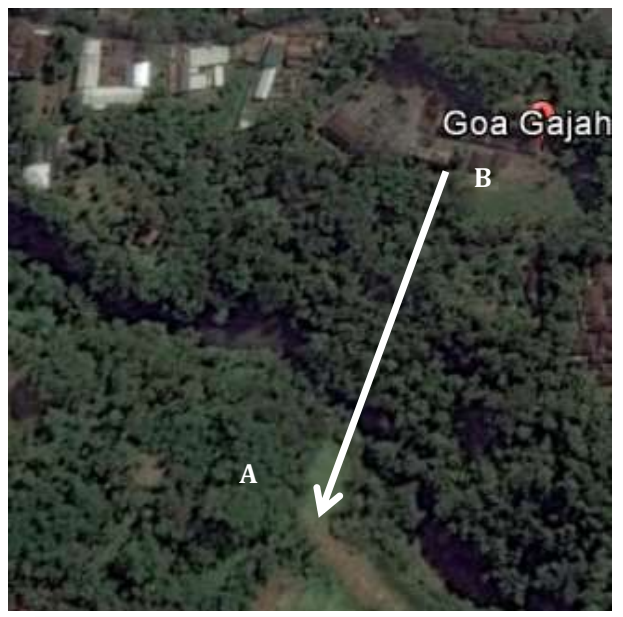

Gambar 7. Arah Stratigrafi Batuan

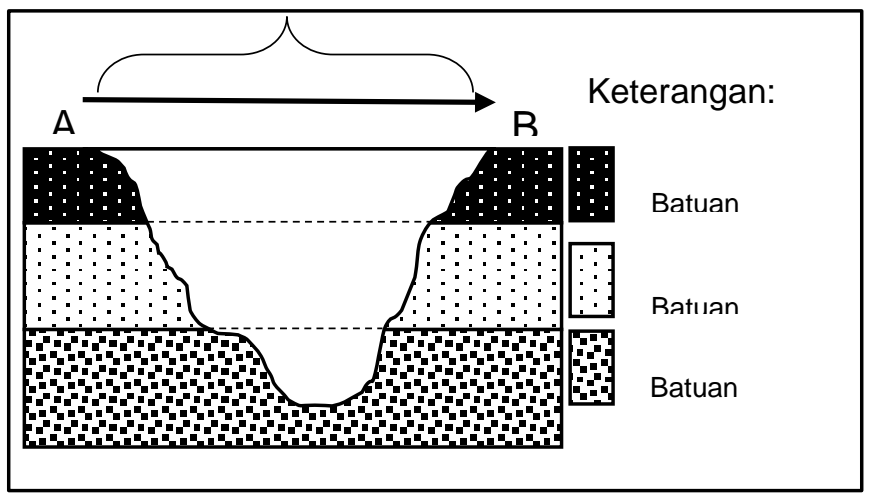

Gambar 8. Stratigrafi Batuan Objek wisata Goa Gajah 
Sedimentasi pada masing-masing batuan ini diduga sangat lama sehingga terjadi kompaksi pada masing-masing batuan. Pada batuan sedimen ini berlangsung pembajian pada bagian tengah dengan menpisnya lapisan batuan. Proses pembajian ini diduga disebabkan oleh gerakan air sungai dalam waktu yang sangat lama. Aktivitas tektonik seperti gempa memepngaruhi batuan hanya membentuk kekar-kekar dan tidak ditemukan sesar, sehingga dalam stratigrafi tidak terdapat pengangkatan atapun intrusi batuan.

\section{Peran Geowisata Dalam Eksplorasi Informasi Pada objek Goa Gajah}

Peran Geowisata adalah memberi informasi wisata berkelanjutan yang berfokus pada kenampakan geologis permukaan bumi dalam rangka mendorong pemahaman akan lingkungan hidup dan budaya, serta dapat memeberikan apresiasi dan konservasi serta kearifan lokal yang terdapat pada objek wisata Goa Gajah. Karena selama ini belum ada apresiasi dari pemerintah dan masyarakat tentang kenampakan geologis dan lingkungan yang mendukung keberadaan objek wisata yang kaitannya terhadap keberadaan jejak arkeologi pada objek wisata, sehingga pengembangan pariwisata diarahkan kepada pengembangan Geowisata untuk menjadi daya tarik wisatawan secara ilmiah dan memahami kondisi geografi dan geologis, sehingga geowisata selain memiliki manfaat ilimiah juga memiliki nilai jual yang berorientasi pada:

1) Geologically based

Jenis batuan ignimbrite, breksi vulkanik memiliki formasi yang paling banyak membentuk komposisi batuan pada kedua objek wisata tersebut, selain itu aktivitas tektonik yang mempengaruhi terbentuknya sesar sesar aktif pada kedua objek sehingga memberikan tambahan nilai estetika pada objek sepertihalnya Goa Gajah yang berbentuk pazel karena tektonik yang membentuk sesar lapisan dan sesar ekstrensi.

2) Suistanable

Dengan ditemukannya jejak arkeologi menjadi wisata yang memliki nilai korelasi tinggi antara jejak arkeologi berupa patung dan wujud lain dengan batuan pembentuk batuan yang terdapat di masing-masing objek wisata tersebut.

3) Geologically informative

Goa Gajah terbentuk dari akivitas vulkanik yang secara umum didominasi dari aktivitas Gunung Batur Purba yang telah mengalami letusan 29.300 tahun yang lalu. Material tersebut kemudian menghendap dan membentuk dasar-dasar Pulau Bali. Berdasarkan materi endapan yang terdapat pada wilayah objek wisata Goa Gajah lebih dominan batuan ignimbrite, breksi vulkanik, lapilli tuff dan andesit.

Penelitian sejenis dilakukan oleh Anggreswari \& Jayaningsih (2018) tentang Potensi Wisata Alam Bebasis Geologi di Hidden Canyon, Desa Guwang Beji, Kabupaten Gianyar, Provinsi Bali menyatakan bahwa "tempat wisata Hidden Canyon merupakan alur sungai yang membentuk lembah dimana batuan penyusun lokasi tersebut berasal dari batuan hasil proses vulkanisme gunungapi Batur purba dengan litologi berupa batupasir vulkanik, breksi vulkanik dengan struktur sedimen berupa silangsiur, gradasi normal hingga massif. Keindahan geologi dapat dijadikan geowisata sehingga dapat memberikan wawasan kepada para wisatawan mengenai proses - proses yang membentuk keindahan objek wisata tersebut".

Objek wisata Goa Gajah tersusun atas batuan andesit sebagai batuan basal terletak pada bagian atas, lapilli tuff, dan breksi vulkanik pada bagian bawah hingga dasar Sungai Petanu. Komposisi, batuan ignimbrite memiliki volume yang lebih besar daripada jenis batuan lainnya pada objek wisata tersebut. Jejak arkeologi yang terbentuk dari lapilli tuff seperti bagaian bawah lebih cepat korosi karena memiliki tingkat kekerasan yang lemah dibandingkan dengan batuan basal (andesit) atau ignimbrite.

Aktivitas tektonik dan vulkanik telah membentuk kekar dan sesar pada kedua objek wisata tersebut. Sesar yang lebih banyak mulai dari sesar diagonal pada dinding bagaian atas goa, sesar lapisan dan sesar ekstrensi yang terdapat pada Goa Gajah membentuk rekahan kotakkotak seperti pazel pada bagian goa. Beberapa jurus kekar telah mempengaruhi anatomi goa seperti pintu depan goa yang patah karena jurus kekekar yang melintang sehingga bentuk pintu goa tidak simetris lagi. Akan tetapi dengan jenis mineral silika berupa plagioklas, kuarsa, 
piroksen, dan biotit yang saling mengikat (interlocking) pada batuan andesit menyebabkan jejak arkeologi Goa Gajah tetap kokoh.

Peran geowisata terlihat sangat signifikan dalam mengungkap peran geologi dalam pengembangan pariwisata. Jika dikorelasikan antara geografis wilayah dan histori serta jejak arkeologi dari dinasti udayana, bahwa posisi kerajaan serta bangunan lokasi-lokasi penting pada jaman itu lebih banyak di dirikan pada tepian atau lembah sungai. Berdasarkan kajian geologi dasar, keberlanjutan dan informasi kegeologisan ditunjang dari sector geografis bahwa lembah sungai dipilih karena lembah sungai sangat identik dengan sumber air yang melimpah baik dari aliran maupun sumber mata air dan sedimentasi alluvial sebagai salah satu indicator kesuburan yang kala itu ditunjang dari sektor agraris.

Berdasarkan informasi geologi wilayah objek wisata Goa Gajah tersusun atas endapan piroklastik gunung batur puba dengan fragmen berukuran bom - lapi, sedangkan ukuran lapilli tuff diendapkan pada wilayah dataran rendah. Arca-acra atau peninggalan sejarah yang ditemukan pada lembah sungai atau pada penataran sebagai besar terbentuk dari batuan piroklastik khsusnya ignimbrite. Lokasi ini dijadikan media karena memiliki sedimen yang keras tidak tembus air (porositas rendah) ini mengindikasikan jika dibangun maka bangunan tidak mudah lapuk atau tahan terhadap korosi. Di sisi lain batuan piroklastik sebagai bahan induk yang secara umum tersusun dari mineral sialis dan ferromagnesa yang memiliki kemampuan interlocing sehingga batuan tersebut bisa kuat dan tahan sampai saat ini. Hal ini dibuktikan dengan konsi goa gajah yang masih tetap bertahan dan memiliki anatomi yang jelas sampai saat ini.

\section{Simpulan dan Saran}

Berdasarkan urain tersebut dapat ditarik kesimpulan sebagai berikut. Goa Gajah tersusun atas batuan andesit lapilli tuff, dan breksi vulkanik. Sedangkan sesar yang lebih banyak mulai sesar diagonal, sesar lapisan dan sesar ekstrensi yang rekahan kotak-kotak seperti pazel pada bagian Goa. Peran geowisata terlihat sangat signifikan dalam mengungkap peran geologi dalam pengembangan pariwisata khususnya pada objek wisata Gowa Gajah. Jejak arkeologi dari dinasti udayana lebih banyak di dirikan pada tepian atau lembah sungai dari limpasan erupsi gunung Batur Purba dengan endapan piroklastik serta memiliki kemampuan interlocing yang kuat.

Saran yang dapat disampaiakan dalam penelitian ini adalah sebagai berikut. Penelitian ini hanya menggunakan farameter fisik dalam menganalisis kondisi geologi wilayah penelitian, untuk memperoleh hasil yang lebih konferhensip dalam penelitian selanjutnya perlu dilakukan tinjauan-tinjauan yang lebih mengkusus dan menggunakan alat untuk dapat mengidentifikasi jenis mineral dengan detail. Penelitian ini hanya mengacu pada dua objek, untuk peneliti selanjutnya dapat mengembangkan cakupan penelitian perlu ditambahkan objek-objek lain yang berada disekitar, bahkan objek geologis yang ada di luar wilayah Gianyar.

\section{Daftar Pustaka}

Anggreswari, N. P. Y., \& Jayaningsih, A. A. R. (2018). Pemberdayaan Masyarakat Melalui Pengembangan Objek Wisata Hidden Canyon Beji Guwang. Jurnal Ilmiah Ilmu Sosial, 4(1), $30-40$.

Assidigy, M. R. (2015). Struktur Geologi Bali dan Nusa Tenggara. Retrieved September 19, 2016, from https://www.academia.edu/12174893/Struktur_Geologi_Bali_dan_Nusa_Tenggara

Hermawan, H., \& Ghani, Y. A. (2017). Geowisa Solusi Pemanfaatan Kekayaan Geologi yang Berwawasan Lingkungan. Bandung: Universitas BSI Bandung.

Juniawati, N. P. E. (2011). Penyajian Informasi Arkeologis di Objek Wisata Pura Goa Gajah. Forum Arkeologi, 14(2), 150-161.

Latief, F. (2014). Candi Gunung Kawi, Petra dari Tampaksiring. Retrieved September 22, 2015, from

http://googleweblight.com/?lite_url=http://nationalgeographic.co.id/berita/2014/05/c 
andi-gunung-kawi-petra-dari-tampaksiring\&ei=0 pRl6MRc\&lc=id-

ID\&s=1\&m=120\&host=www.google.co.id\&ts=1474208737\&sig=AKOVD65370lH Iynm_FXU6J2hc-Zfksde9Q

Mahardika, P. (2015). Geodiversity. Retrieved September 22, 2016, from http://www.baturglobalgeopark.com/index.php/profil/14/Geodiversity.html

Mudana, I. G. (2018). Memadukan Pendakian dan Wisata Edukasi: Persoalan Gunung Api dan Geopark Batur di Kawasan Kintamani, Bali. Jurnal Kajian Bali, 8(2).

Mudana, I. W. (2013). Ideologi Nyegara Gunung: Sebuah Kajian Sosiokultural Kemiskinan Pada Masyarakat Pesisir Di Bali Utara. Jurnal Ilmu Sosial Dan Humaniora, 2(1), 138-149.

Puja, M. (2015). Sejarah Pura Goa (Gua) Gajah Bedahulu - Gianyar - Bali. Retrieved September 19, 2016, from http://www.id.sorgabalitours.com/2015/08/sejarah-pura-goa-gua-gajahbedahulu-gianyar-bali.html

Riswanto, A., \& Andriani, R. (2018). Maksimalisasi Potensi Geowisata dalam Meningkatkan Kunjungan Wisatawan. Jurnal Pariwisata, 5(2).

Setyawan, A. (2013). Prinsip Geowisata (Geotourism Principles). Retrieved September 23, 2016, from https://geograph88.blogspot.co.id/2013/07/prinsip-geowisata-geotourismprinciples.html 